О. М. Разнатовська, О. А. Мурзіна, О. І. Потоцька, Г. М. Алексєєва

Запорізький державний медичний університет, м. Запоріжжя, Бердянський державний педагогічний університет, м. Бердянськ

\title{
АКТУАЛЬНІСТЬ ВПРОВАДЖЕННЯ В ОСВІТНІЙ ПРОЦЕС СТУДЕНТІВ-МЕДИКІВ ІНТЕРАКТИВНИХ МЕТОДІВ НАВЧАННЯ
}

\author{
O. M. Raznatovska, O. A. Murzina, O. I. Pototska, H. M. Alekseeva \\ Zaporizhzhia State Medical University, Zaporizhzhia, \\ Berdiansk State Pedagogical University, Berdiansk

\section{RELEVANCY OF INTERACTIVE METHODS OF TEACHING IMPLEMENTATION IN THE EDUCATIONAL PROCESS OF MEDICAL STUDENTS}

\begin{abstract}
Мета роботи - провести огляд літератури щодо використання інтерактивних методів навчання у вищих навчальних закладах, у тому числі й медичних, та їх значення в освітньому процесі.

Основна частина. Вища освіта залишається важливою складовою сучасної спільноти. 3 підвищенням вимог до компетентностей майбутніх лікарів зростає необхідність вищої медичної освіти в організації та впровадженні новітніх якісних технологій навчання та викладання, які будуть сприяти підтримці конкурентоспроможності. При цьому якість освіти значно залежить від взаємодії між викладачем та студентом. Тому на сьогодні актуальності набувають інтерактивні методи навчання. Інтерактивні методи навчання визначають не лише активний зворотний зв'язок між викладачем та студентами, але й організацію взаємодії між самими студентами, що об'єднує студентів та дає їм можливість працювати в групі (сумісно вирішувати складні питання, моделювати різні ситуації з визначеної дисципліни тощо). Такий підхід у навчанні має фахове спрямування та надає змогу впливати на інтелектуальний та професійний розвиток, аргументовано висловлюватися та захищати свою точку зору, створює умови для формування та розвитку професійних навиків, критичного мислення, розвитку комунікативних компетенцій та самостійної роботи.

Висновки. Проведений огляд літератури свідчить про те, що існує достатньо методів інтерактивного навчання, які застосовуються у вищих навчальних закладах, і вони є ефективними. Тому більш широке впровадження в освітній процес студентів-медиків інтерактивних методів на сьогодні є актуальним та одним із важливих направлень удосконалення навчання, що сприятиме підвищенню методичного рівня професійної підготовки, розвитку компетентностей студентів і формуванню вмінь та навиків, необхідних для майбутньої професії.
\end{abstract}

Ключові слова: освітній процес; студенти; інтерактивні методи навчання.

The aim of the work - to review literature on the use of interactive teaching methods in higher education institutions, including medical ones, and their importance in the educational process.

The main body. Higher education remains an important part of the modern community. Increasing demands on the competences of future physicians increase the need for higher medical education in the organization and implementation of the latest highquality teaching and learning technologies that will promote competitiveness. In this case, the quality of education to a great extent depends on the interaction between the teacher and the student. Therefore, today the relevance of interactive learning methods is acquired. Interactive teaching methods determine not only the active feedback between the teacher and the students, but also the organization of interaction between students, that unites students, and gives them the opportunity to work in a group (to solve complex problems together, to simulate different situations in a certain discipline and etc.). Such study approach has specialist direction and allows them to influence intellectual and professional development, to reasonably express and defend their point of view, creates conditions for the formation and development of professional skills, critical thinking, development of communicative competences and independent work.

Conclusions. Literature review suggests that there are enough interactive teaching methods that are applied in higher education institutions and are effective. Therefore, the widespread introduction of interactive methods among medical students in the educational process is relevant and is one of the important directions of education improvement which will increase the methodical level of professional training, development of students' competences and formation of the skills required for the future profession.

Key words: educational process; students; interactive teaching methods.

(с) О. М. Разнатовська, О. А. Мурзіна, О. І. Потоцька, Г. М. Алексєєва 
Вступ. Вища освіта залишається важливою складовою сучасної спільноти. 3 підвищенням вимог до компетентностей майбутніх лікарів зростає необхідність вищої медичної освіти в організації та впровадженні новітніх якісних технологій навчання та викладання, які будуть сприяти підтримці конкурентоспроможності [1]. При цьому якість освіти значно залежить від взаємодії між викладачем та студентом. Тому на сьогодні актуальності набувають інтерактивні методи навчання.

Мета роботи - провести огляд літератури щодо використання інтерактивних методів навчання у вищих навчальних закладах, у тому числі й медичних, та їх значення в освітньому процесі.

Основна частина. "Роль викладача $є$ вирішальною у створенні високоякісного досвіду студентів та уможливленні набуття знань, компетентностей і навичок” [1]. Викладачі вищих навчальних закладів, у тому числі й медичних, мають використовувати у своїй діяльності сучасні новітні та оптимальні технології викладання, які повинні бути направлені, в першу чергу, на створення творчої атмосфери серед студентів [2]. Такими технологіями є активні та інтерактивні методи навчання.

Активні методи навчання несуть в собі активний зворотний зв'язок між викладачем та студентами [2-4]. А інтерактивні методи, які є одним із сучасних направлень активних методів, визначають не лише активний зворотний зв'язок між викладачем та студентами, але й організацію взаємодії між самими студентами, що об’єднує студентів та дає їм можливість працювати в групі (сумісно вирішувати складні питання, моделювати різні ситуації з визначеної дисципліни тощо) [5]. При цьому викладач $є$ головною фігурою навчального процесу, первинними завданнями якого є створити умови для підвищення ініціативи студентів, направлення їх діяльності на досягнення мети заняття та домінування активності студентів у процесі навчання [6].

Такий підхід у навчанні має фахове спрямування та надає змогу впливати на інтелектуальний та професійний розвиток, аргументовано висловлюватися та захищати свою точку зору, створює умови для формування і розвитку професійних навиків, критичного мислення, розвитку комунікативних компетенцій та самостійної роботи.

Шляхом інтерактивних методів навчання можуть проводитися як практичні заняття, так і лекції.

У статті Е. Л. Дмитриева зі співавт. (2014) [6] описано принципи та методики інтерактивних форм навчання, які прийнятні для застосування в освітньому процесі вищих навчальних закладів. Це обговорення в групах, творче завдання, публічна презентація проекту, дискусія (публічне обговорення проблеми), ділова гра (моделювання проблеми методом пошуку нових способів ії̈ виконання), кейс-метод (рішення конкретних задач), інтерактивна лекція, розробка проекту (формування дослідницьких вмінь та аналізу літературних джерел), перегляд й обговорення відеофільмів, тренінги (формування компетентності міжособистісної і професійної поведінки в спілкуванні), круглі столи (ретельний аналіз конкретної ситуації в міжособистісних стосунках), колоквіуми (групове обговорення під керівництвом викладача широкого кола проблем), методики “дерево рішень” (оволодіння навичками вибору оптимального варіанта рішення проблеми) та “мозковий штурм” (створення психоевристичного мікроклімату в малих групах для підвищення ефективності вирішення творчих задач), проблемне навчання. Автори вказують на те, що для кращого осмислення навчального матеріалу та вирішення проблеми студентами викладач у ході підготовки до конкретного заняття на основі інтерактивних методів має обрати найбільш ефективні та відповідні форми навчання з поєднанням кількох таких методів.

Н. Д. Сергеева зі співавт. (2016) [7] у своїй роботі розкривають на власному прикладі актуальність та ефективність застосування у медичних вузах таких інтерактивних методів навчання, як ділові та рольові ігри, кейс-метод та семінари-дискусії. Так вони вказують на те, що застосування рольових ігор, підвищуючи інтерес до теми заняття, сприяють кращому засвоєнню навчального матеріалу та формують клінічне мислення. Застосування семінарів-дискусій дозволяють студентам придбати такі навички, як вміння відстоювати свою думку, володіючи теоретичним матеріалом, слухати інших, робити узагальнюючі висновки. Використання кейс-методу у невеликих групах студентів сприяє формуванню таких навичок, як виявлення та рішення складних проблем і непередбачених ситуацій, аналіз отриманої інформації, проявлення власної ініціативи та прийняття самостійного рішення.

За даними Е. А. Леушиной та Н. А. Леушиной (2015) [5], застосування ігрових методів основані на організації взаємодії в ситуаціях, що моделюють певний цикл професійної діяльності. Такий інтерактивний метод навчання дозоляє вирішити завдання, пов'язані з поведінкою: сформувати у студентів моделі поведінки в ситуаціях міжосо- 
бистісної взаємодії, формування вміння усунення гострих переживань проблеми та ін.

В. Г. Лалетин зі співавт. (2016) [8] вказують на те, що інтерактивні методи навчання (кейс-метод, тренінги та інтерактивні лекції) у студентів-медиків повинні мати виховальний та розвиваючий характер, що сприятиме формуванню не лише клінічного мислення, а й також терпимості до слабкостей хворих, стриманості та безкорисності майбутнього лікаря, шанобливого ставлення як до пацієнтів, так і до колег.

А. А. Вендина зі співавт. (2016) [9], провівши аналіз застосування у студентів таких інтерактивних форм навчання, як метод критичного мислення, уявний експеримент, метод опису, проблемне навчання, ігрові методи, “мозковий штурм”, дискусія та метод проектів, зробили такий висновок. Застосування цих інтерактивних методів навчання у студентів сприяють не лише інтенсифікації процесу розуміння та формуванню професійних компетентностей, а також стимулюють студентів до подальшої пізнавальної активності.

У роботі Ю. В. Гущина (2012) [10], окрім вищеописаних інтерактивних методів навчання, значна увага приділяється застосуванню у студентів методу портфоліо, який має такі функції в освітньому процесі: діагностичну, цілепокладання, мотиваційну, інформаційну, оцінювання та контролюючу. За даними автора, цей метод сприяє організації студентом власної навчальної діяльності, формуванню самостійності, оцінці перспектив професійного росту, визначенню динаміки навчально-пізнавальної діяльності та труднощів у засвоєнні навчального матеріалу.

\section{Список літератури}

1. Стандарти і рекомендації щодо забезпечення якості в Європейському просторі вищої освіти (SEG). - K. : ТОВ “ЦС”, 2015.

2. Мухина Т. Г. Активные и интерактивные образовательные технологии (формы проведения занятий) в высшей школе : учебное пособие / Т. Г. Мухина. Н. Новгород : ННГАСУ, 2013. - 97 с.

3. Ипатова Л. О. Активные методы обучения как важный фактор активизации учебного процесса в высшей школе / Л. О. Ипатова // ФӘН-Наука. - 2012. № 12. - С. 72-74.

4. Иванченко М. А. Активные и интерактивные методы обучения в высшей школе / М. А. Иванченко // Гуманитарные и социальные науки. - 2014. - № 2. C. 373-377.

5. Леушина Е. А. Классификация методов обучения в педагогической деятельности / Е. А. Леушина, Н. А. Леу-
На сьогодні велике значення надається проведенню інтерактивних лекцій, що створює атмосферу співробітництва між викладачем та студентами. Виділяють такі види інтерактивних лекцій [10], як: проблемна лекція (під час лекції створюються проблемні ситуації), лекція-провокація (викладач навмисно робить помилки в процесі лекції, а студенти по ії̈ завершенні мають їх озвучити), лекціявізуалізація (використання рисунків, відеофільмів та ін.), лекція “прес-конференція” (студентам надається можливість зробити письмові запитання до лектора перед початком лекції) та лекція-діалог (у процесі лекції студенти відповідають на поставлені їм запитання).

Інтерактивні лекції завдяки співробітництву між викладачем та студентами дозволяють: сконцентрувати увагу студентів на аудиторній роботі; в процесі лекції уточнювати незрозумілі моменти, що закріпить отриману інформацію; сформувати критичне мислення. При цьому у викладача $є$ можливість у процесі лекції оцінювати якість та швидкість засвоєння студентами лекційного матеріалу.

Висновки. Проведений огляд літератури свідчить про те, що існує достатньо методів інтерактивного навчання, які застосовуються у вищих навчальних закладах, і вони є ефективними. Тому більш широке впровадження в освітній процес студентів-медиків інтерактивних методів на сьогодні $€$ актуальним та одним із важливих направлень удосконалення навчання, що сприятиме підвищенню методичного рівня професійної підготовки, розвитку компетентностей студентів та формуванню вмінь та навиків, необхідних для майбутньої професії.

шина // Вектор науки ТГУ. Серия: Педагогика, психология. - 2015. - № 3 (22). - С. 119-122.

6. Применение интерактивных методов в образовательном процессе высшей школы / Е. Л. Дмитриева, О. А. Тиняков, Е. Н. Бурдастых, Н. С. Малышева // Электронный научный журнал Курского государственного университета. - 2014. - С. 3-5.

7.Интерактивные методы обучения в медицинском вузе / Н. Д. Сергеева, И. Ю. Данилова, Т. К. Шкавро, Л. Р. Колесникова // Система менеджмента качества: опыт и перспективы. - 2016. - Вып. 5. - С. 44-47.

8. Интерактивные методы обучения студентов на кафедре онкологии и лучевой терапии ИГМУ / В. Г. Лалетин [и др.] // Система менеджмента качества: опыт и перспективы. - 2016. - Вып. 5. - С. 27-30.

9. Вендина А. А. Активные и интерактивные методы обучения как средство подготовки бакалавров педагоги- 
ческого образования к реализации требований ФГОС / А. А. Вендина, К. А. Киричек, В. В. Малиатаки // Интернет-журнал “Мир науки”. - 2016. - T. 4, № 2. - URL : http://mir-nauki.com/PDF/54PDMN216.pdf.

\section{References}

1. (2015). Standarty i rekomendatsii shchodo zabezpechennia yakosti $v$ Yevropeiskomu prostori vyshchoi osvity (SEG) [Standards and Guidelines for Quality Assurance in the European Higher Education Area (ESG)]. Kyiv: TOV "CS" [in Ukrainian].

2. Mukhina, T.G. (2013). Aktivnye i interaktivnye obrazovatelnye tekhnologii (formy provedeniya zanyatiy) $v$ vysshey shkole: uchebnoe posobie [Active and interactive educational technologies (forms of conducting classes) in higher education: a textbook]. N. Novgorod [in Russian].

3. Ipatova, L.O. (2012). Aktivnye metody obucheniya, kak vazhnyy faktor aktivizatsii uchebnogo protsessa $\mathrm{v}$ vysshey shkole [Active methods of teaching as an important factor in the activation of the educational process in higher education]. FəN-Nauka - FəN-Science, 12, 72-74 [in Russian].

4. Ivanchenko, M.A. (2014). Aktivnye i interaktivnye metody obucheniya v vysshey shkole [Active and interactive teaching methods in higher education]. Gumanitarnye i sotsialnye nauki - Humanities and Social Sciences, 2, 373-377 [in Russian].

5. Leushina, E.A., \& Leushina, N.A. (2015). Klassifikatsiya metodov obucheniya $\mathrm{v}$ pedagogicheskoy deyatelnosti [Classification of teaching methods in pedagogical activity]. Vektor nauki TGU. Seriya: Pedagogika, psikhologiya Vector of Science TSU. Series: Pedagogy, Psychology, 3 (22), 119-122 [in Russian].

6. Dmitriyeva, E.L., Tinyakov, O.A., Burdastykh, E.N., \& Malysheva, N.S. (2014). Primenenie interaktivnykh metodov v obrazovatelnom protsesse vysshey shkoly [The application of interactive methods in the educational process
10. Гущин Ю. В. Интерактивный методы обучения в высшей школе [Электронный ресурс] / Ю. В Гущин // Психологический журнал. - 2012. - № 2. - С. 1-18. Режим доступа : www.psyanima.ru. of higher education]. Elektronnyy nauchnyy zhurnal Kurskogo gosudarstvennogo universiteta - Electronic Scientific Journal of the Kursk State University, 3-5 [in Russian].

7. Sergeeva, N.D., Danilova, I.Yu., Shkavro, T.K., \& Kolesnikova, L.R. (2016). Interaktivnye metody obucheniya v meditsinskom vuze [Interactive methods of teaching in a medical school]. Sistema menedzhmenta kachestva: opyt $i$ perspektivy - Quality Management System: Experience and Prospects, 5, 44-47 [in Russian].

8. Laletin, V.G., Galchenko, L.I., Dvornichenko, V.V., Belonogov, A.V., \& Matochkin, V.V. (2016). Interaktivnye metody obucheniya studentov na kafedre onkologii i luchevoy terapii IGMU [Interactive methods of teaching students at the Department of Oncology and Radiation Therapy at IGMU]. Sistema menedzhmenta kachestva: opyt i perspektivy - Quality Management System: Experience and Prospects, 5, 27-30 [in Russian].

9. Vendina, A.A., Kirichek, K.A., \& Maliataki, V.V. (2016). Aktivnye i interaktivnye metody obucheniya kak sredstvo podgotovki bakalavrov pedagogicheskogo obrazovaniya k realizatsii trebovaniy FGOS [Active and interactive teaching methods as a means of preparing bachelors of teacher education for the implementation of GEF requirements]. Internet-zhurnal "Mir nauki" - Internet-Journal “The World of Science”, 4, 2. - Retrieved from: http://mirnauki.com/PDF/54PDMN21.6.pdf [in Russian].

10. Gushhin, Yu.V. (2012). Interaktivnyy metod obucheniya $\mathrm{v}$ vysshey shkole [Interactive methods of teaching in higher education]. Psihologicheskiy zhurnal Psychological Journal, 2, 1-18. Retrieved from: www. psyanima.ru [in Russian].

Електронна адреса для листування: raxnatovskaya@gmail.com

Отримано 23.03.18 